\title{
Albergue Espanhol: A Lenda Negra sobre o comer e o beber madrileños pelo olhar de viajantes franceses (século XIX)
}

DOI

http://dx.doi.org/10.1590/2236-463320161309
Spanish Hostel: The Black Legend about the madrileños eat and drink through the eyes of French travelers (XIXth century)

\section{Daisy de Camargo}

Universidade Federal de São Paulo UNIFESP, Guarulhos - SP, Brasil. daisydecamargo@yahoo.com.br

\section{Resumo}

Este texto, resultado parcial de minha pesquisa sobre a história das tabernas na cidade de Madri, centra o foco na percepção dos costumes do comer e beber, no viés da abordagem de relatos de escritores franceses do século XIX que estiveram em Madri: Alexandre Dumas, Théophile Gautier, Prósper Merimée e Jean-Charles Davillier.

Esses escritores de cultura francesa - e mais especificamente parisiense criaram a fama da Espanha Negra no que diz respeito à comida e à bebida. Tais literatos, advindos de classes abastadas, espalharam pela Europa uma péssima imagem em relação à mesa e hospitalidade espanholas, sedimentada na expressão "albergue espanhol" - onde se come, bebe e dorme muito mal -, além da ideia de que tudo na Península cheira a alho e vinho de vinagre.

\section{Abstract}

This text is going to present some result of my research about the history of the taverns in the city of Madrid, focusing on the perception of the customs of eating and drinking in the accounts of nineteenth-century French writers who've been to Madrid approach bias: Alexandre Dumas, Théophile Gautier, Prosper Mérimée and Jean-Charles Davillier. These writers of French culture - and more specifically Parisian - created the fame of the Black Spain with regard to food and drink. These writers coming from wealthier classes spread across Europe a lousy image in relation to the table and Spanish hospitality, based on the term "Spanish hostel" - where someone eats, drinks and sleeps very badly - and on the idea that everything in the Peninsula smells like garlic and winevinegar.

\section{Palavras-chave}

Madri; Comida; Bebida; Alexandre Dumas; Théophile Gautier; Prósper Merimée; Jean Davillier.

\section{Keywords}

Madri; Food; Drink; Alexandre Dumas; Théophile Gautier; Prósper Merimée; Jean Davillier. 
Viajar! Perder países!

Ser outro constantemente, Não pertencer nem a mim! [Fernando Pessoa]

Afinal, a melhor maneira de viajar é sentir.

Sentir tudo de todas as maneiras.

Sentir tudo excessivamente,

Porque todas as coisas são, em verdade, excessivas

E toda a realidade é um excesso, uma violência, [Álvaro de Campos]

A metrópole seria a miniatura do universo, 0 molde da imagem da modernidade em volta da qual o mundo circula, como coloca Willi Bolle, em seu estudo sobre Passagens, de Benjamin: "Em suma, a imagem da metrópole como abreviatura do universo está condensada nesta tripla definição das passagens como 'uma cidade, um mundo em miniatura', 'templo do capital mercantil' e 'o molde oco a partir do qual se cunhou a imagem de modernidade'." BOLLE, Willi. Um painel com milhares de lâmpadas: metrópole megacidade. In: BENJAMIN, Walter. Passagens. Belo Horizonte/ São Paulo: UFMG/Imprensa Oficial, 2006. p. 1.143. Pode-se dizer que os padrões franceses tornaram-se referência por toda a Europa e América, por conta do impacto das reformas efetuadas por Georges-Eugéne Haussmann, prefeito de Paris entre 1853 e 1870, como coloca Heloísa Barbuy: "Vários planos urbanísticos, para dar nova conformação às principais cidades da Europa e das Américas, tiveram lugar no século XIX. Traduzindo a maturação desse processo, estabeleceu-se uma nova expressão, que passou a ser de uso corrente: planejamento urbano. 'As expressões town planning, city planning, [...], urbanisme, urbanistica, stadsplanering, stedebouw e gradostroitel'stvo, todas entraram em uso geral entre aproximadamente 1890 e 1914.' 0 século XIX - o longo século XIX, estendido até 1914 - foi, assim, a era de ouro das reurbanizações planejadas. [...]Criava-se um modelo de 'cidade moderna', caracterizado pelas grandes avenidas ordenadoras do tráfego, de linhas retas e axiais, pela presença de esculturas monumentais e imponentes edifícios públicos estrategicamente situados para ser referências espaciais, pelos parques e jardins também minuciosamente planejados, entremeando o tecido urbano. Visibilidade e uniformidade eram os vetores pelos quais se imprimia uma racionalidade funcionalista e se fortalecia a imagem do Estado." BARBUY, Heloisa. A cidade-exposição: comércio e cosmopolitismo em São Paulo (1860-1914). São Paulo: EDUSP, 2006. p. 70. Mas está claro que o raio de influência parisiense não se limitou ao urbanismo, posto que tornou-se referência em diversos campos da cultura e do consumo, tais como nos modos de vestir, comer e beber.
Outrar: poucas criaturas no mundo souberam o que é mergulhar no mundo da experiência como Fernando Pessoa, o criador desse verbo. E o que é viajar senão se deixar tocar pelos sentidos e potências do outro? Mas que tarefa difícil essa de despir-se de si mesmo, ainda mais quando se trata de um olhar centro-europeu - e particularmente parisiense - em relação a uma periferia considerada pobre e retrógrada. Esse tema é um recorte parcial de minha pesquisa de pós-doutorado sobre as casas de comida e bebida, em especial as tabernas, localizadas na cidade de Madri no século XIX e começo do XX.

Entre os relatos dos viajantes do século XIX, muitos dão conta do atraso da história da Espanha e especificamente de Madri, sobretudo por culpa do "orientalismo", herança que carrega traços de corrupção, fanatismo religioso, crueldade e indolência.

Esses escritores às vezes resvalam alguns poucos comentários sobre uma questão enfrentada por qualquer viajante: encontrar alojamento e comida. A maneira com que lêem os hábitos (incluindo os de comer e beber) está mergulhada num amálgama de valorações culturais e estéticas. Estavam embebidos da noção de que Paris era o centro irradiador de modernidade e elegância. A cidade industrializada e com grandes obras urbanas e arquitetônicas reivindica também para si o posto de rainha da mesa e dos gourmets.

Vale retomar o pensamento de Walter Benjamin, que focaliza Paris como a cidade-mãe, cujos problemas e relações culturais interagem com as outras cidades de periferia, como é o caso de Madri.

0 conceito de metrópole como cidade-mãe emerge, portanto, no período do imperialismo oitocentista, sobretudo no que diz respeito a Paris, propulsora de modismos, mas desvelando também o seu contrapeso: o contorno e os marginalizados que nela habitam. ${ }^{1}$ Dentro desse contexto, enquanto periferia europeia, a Espanha é vista como pitoresca e por vezes ameaçadora.

Para os centro-europeus, visitar a Espanha era como desbravar o Egito. Há muito que ver com o fascínio do exótico e nesse departamento a Península não estava longe da África. Eu quero dizer com isso que era um território por descobrir. No século XIX as viagens pelo país viraram moda, inclusive nos meios literários. Houve um boom de publicações de relatos de viagens fazendo referências ao medo dos bandoleiros e ladrões de tocaia pelas estradas, pulgas e a mistura maléfica e envenenada do azeite e do alho.

Essa onda de exploradores também está relacionada com a atração despertada pelo orientalismo ${ }^{2}$ e um imaginário repleto de odaliscas e nar- 
Tomo aqui por orientalismo uma ideia formulada pelo olhar eurocêntrico em relação às sociedades de "fora" do contexto ocidental da cultura européia, muitas vezes abordadas como misteriosas, exóticas e perigosas. Sobre o assunto ver SAID, Edward. Orientalismo: o Oriente como invenção do Ocidente. São Paulo: Companhia das Letras, 2007. Essa visão despertou no século XIX a curiosidade de uma geração que buscava desertos evocadores de Síria e Turquia, edificações orientais (como a Alhambra e Mesquitas); em suma, todo um "espirito oriental" que os românticos perseguiam. BRENAN, Gerald. Prólogo de FORD, Richard. Las Cosas de España. Madrid: Turner, 1988. p. 1.

3

BESAS, Peter. Historia y anécdotas de las fondas madrileñas. Madrid: Ediciones La Librería, 2009. p. 153-154. Sobre o fato das citações de parte da bibliografia e das fontes estarem em lingua espanhola, resulta de que a abordagem da presente pesquisa está centrada geograficamente na cidade de Madri, e disto decorre que o tema diz respeito à repercussão e apropriação dos discursos dos viajantes na Espanha. Por este motivo optouse por manter os textos na versão espanhola (e não em seus idiomas originais e tampouco traduzi-los para o português) receando que sutilezas da fala se perdessem nessas versões.

4

CHARTIER, Roger. História Cultural: entre práticas e representações. Lisboa/Rio de Janeiro: Difel/ Bertrand do Brasil, 1995.

5

DÍEZ BORQUE, José Maria. La vida española en el siglo de Oro según los extranjeros. Barcelona: Ediciones del Serbal, 1990.

6

JUNQUEIRA, Mary Anne. Elementos para uma discussão metodológica dos relatos de viagem como fonte para o historiador. In: FRANCO, Stella Maris Scatena. (orgs.) Cadernos de Seminários de Pesquisa. São Paulo: USP/Humanitas, 2011, v. 2, p. 44-61, p. 48-49.

7

MERIMÉE, Prosper. Viajes a España. Madrid: Aguilar, 1988. p. 15-16.

8

Mary Junqueira aponta para a questão dos relatos de viagem como gênero híbrido, que pode compreender naturezas plurais. JUNQUEIRA, $0 p$. Cit. p. 44-61.

9

0 período em que o texto foi escrito também deve ser levado em consideração, posto que ajuda a entender o mundo em que está situado esse autor. Ibidem, pp. 44-61. guilés. Claro que esses cenários típicos de haréns não existiam mais na Espanha desse periodo, mas sobreviveram os incriveis palácios mouros e 0 perfume do oriente na comida atrevidamente condimentada.

Essa inclinação pelo "pitoresco" também tem de ser vista sob o contexto da colonização. Foi nesse período que a França ocupou a Argélia, Tunísia e parte de Marrocos. ${ }^{3}$ Todo esse fluxo se converteu numa verdadeira horda de fluxo de viajantes.

É dentro desse contexto que esse artigo pretende ser um exercício de perceber os costumes do receber, comer e beber, através do arrolamento da abordagem de relatos e descrições de escritores franceses do século XIX que estiveram em Madri: Alexandre Dumas, Théophile Gautier, Prósper Merimée e Jean-Charles Davillier.

Tomando por base os estudos de Roger Chartier, a intenção foi interpelar essas narrativas não como testemunho, mas sim como percepção ativa do indivíduo que cria significados a partir de suas experiências particulares e do meio social do qual faz parte.

É nessa trilha que parto da noção de história cultural esboçada por Chartier - enquanto história social das interpretações ou da construção de significados ${ }^{4}$ - que lê o indivíduo situado numa série de reciprocidades e configurações sociais e ao mesmo tempo como criador de representações e práticas. A questão é apreender campos de leitura, interpretações móveis, plurais e até contraditórias em relação aos hábitos do comer e do beber.

José Maria Díez Borque ${ }^{5}$ chama atenção para a importância dos motivos da viagem, no que diz respeito a esse tipo de fonte. Essa observação pode ser um bom caminho para organizar, esboçar uma tipologia e decupar os relatos, quer seja, compreender as balizas da perspectiva desse olhar viajante, posto que o propósito da jornada pode afetar a visão de Espanha que é transmitida.

Também é sempre bom lembrar que esse esses relatos pressupõem um leitor. E ainda: a narrativa no mais das vezes engendra inspiração para outros viajantes. ${ }^{6}$ Esses testemunhos foram escritos em formato de cartas endereçadas a seus interlocutores, muitas vezes intelectuais. Entretanto, os textos já assumem desde o início, claras intenções literárias, visando uma publicação posterior em formato de livro. Merimée chega a explicitar essa aspiração, quando em uma das cartas a Jenny Dacquin insinua que se eles continuassem se escrevendo naquele ritmo, não cabia outro recurso senão cuidar do estilo e logo publicaria sua correspondência, como teria feito Balzac. $^{7}$

É preciso ponderar que esses relatos transformaram-se em verdadeiros vade-mécuns dos que se aventuraram por explorar a Espanha. Chega-se aqui numa outra questão que é o alcance do relato como gênero híbrido, a saber: um amálgama de memórias, diários, cartas, guias de viagem e literatura. ${ }^{8}$ De todo modo, o interesse pela "exótica" Ibéria entre os centro-europeus e o aumento do fluxo de viajantes geraram um público leitor interessado que esses escritores souberam visar.

Mesmo com a ciência de que todos os relatos são únicos, procurei centrar o foco num certo corpus documental que implica num bloco de entendimento e uma coerência de gêneros: quatro escritores de cultura francesa - e mais especificamente parisiense - que visitaram o pais no século XIX ${ }^{9}$ e criaram a fama da Espanha Negra no que diz respeito à comida e à bebida. ${ }^{10}$ Esses literatos advindos de classes abastadas espalharam pela Europa uma péssima imagem em relação à mesa e à hospitalidade espanho- 
Alguns outros viajantes foram citados como fontes circunvizinhas e de maneira pontual.

11

SPÍNOLA, Carlos. Los cuatro jinetes del Apocalipsis de la gastronomía andaluza. Revista GastroSur, Cádiz, n. 3, p. 3-5, 2005.

12

BESAS, Peter. Op. Cit., p. 180.

13

BYRNE, Julia Clara Pitt. Cosas de España. London, New York: Alexander Strahan, 1866. p. 22

14

BYRNE, Julia Clara Pitt., p. 27.

15

Dumas Davy de la Pailleterie (Villers-Cotterêts, próximo a Paris, 1802 - Puys, 1870). Era neto do marquês de Antoine-Alexandre Davy de la Pailleterie e filho do General Dumas. Escreveu peças de teatro, romances e crônicas históricas que lhe renderam fama, tais como: 0 Conde de Monte Cristo e Os Três Mosqueteiros. las" ${ }^{11}$, sedimentada na expressão "albergue espanhol" - onde se come, bebe e dorme muito mal - e a ideia de que tudo na Península cheira a alho e vinho de vinagre.

\section{0 grande chef, gourmet e especialista gastronômico: Alexandre Dumas}

Julia Clara Pitt Byrne (Mrs. William Pitt Byrne), uma viajante britânica, nascida em Busk, publicou em 1866 um livro intitulado Cosas de España. Byrne era esposa do proprietário do The Morning Post e visitou o pais, donde redigiu um raconto importante. Já havia escrito vários livros sobre outras nações (Interiores Flamencos, 1856; Castelos de França, 1869, entre outros). ${ }^{12}$ Apesar de manter a famigerada aversão ao azeite, que considera repugnante, é dotada de um espírito livre e inquieto. É um dos relatos que mais fazem menção às casas de comida para as classes mais baixas, de lugares mais simples, inclusive aqueles em que as pessoas levavam viveres para cozinhar e compravam bebidas do estabelecimento:

\begin{abstract}
En los suburbios, un gran número entre los restaurantes de clase baja tienen colocados unos carteles anunciando que las personas pueden traer sus propios comestibles y cocinarlos en el establecimiento. Esto sin duda es una reliquia de la práctica, todavía no obsoleta y tan esencialmente española, en virtud de la cual el fatigado viajero no encontró ningún alojamiento más allá de cuatro paredes desnudas y un techo, y tenía que llegar abastecido, no sólo con el apetito bien abierto, sino con todo lo que era necesario para satisfacerlo. ${ }^{13}$
\end{abstract}

Entretanto, o desprendimento de Pitt Byrne não era regra entre os escritos abordados. Grande parte dos viajantes centro-europeus preferiam comer nas fondas onde se hospedavam (de preferência as gerenciadas por franceses ou outra estirpe mais valorizada do ramo) do que se arriscar em lugares desconhecidos e de classe baixa que horrorizariam o estrangeiro de elite.

Ao que parece, Byrne se aventurou por esses lugares mais populares, onde, segundo a escritora, podia-se jantar sopa, três pratos, sobremesa e vinho por apenas seis reales ou comer um cocido previamente encomendado com todos os rituais que esse prato demanda: caldo, chorizo, toucinho, aves e mais quatro classes de carne. ${ }^{14}$

Esse não foi o caminho percorrido por Alexandre Dumas ${ }^{15}$, que vai a Madri em 1846 para cobrir a cerimônia do casamento da rainha Isabel com Don Francisco de Asís e de sua irmã Luísa Fernanda com um nobre francês, duque de Montpensier. Foi enviado como correspondente pelos periódicos parisienses La Presse e Le Constitutionel. 0 escritor, que a essa altura tinha status de celebridade com direito a viagem de alto conforto e circunstância, acompanhado de séquito que incluia alguns escritores e artistas parisienses (como Louis Boulanger, Auguste Maquet) e um filho ilegitimo (de Dumas), Alexandre (autor de A Dama das Camélias). Quando chegou à capital a tal comitiva (abastecida com três baús de roupas e seis cofres com escopetas e pistolas) foi engrossada pelos artistas Adolphe Desbarolles e Eugène Giraud.

Suas impressões, publicadas em De Paris a Cádiz foram escritas em formato de cartas destinadas a uma amiga imaginária fixada na capital francesa, o que reporta para onde seu mundo gira. De todos os escritos recolhidos é o que mais depura detalhes gastronômicos da viagem e é também o que 
DUMAS, Alexandre. De París a Cádiz: impressiones de viaje. Valencia: Pre-textos, 2002, p. 53-54. mais toma a superioridade da comida francesa como uma verdadeira fé. Dumas, como quase todo cidadão parisiense que se preze, considerava-se um gourmet e a essa altura havia inclusive escrito um guia de gastronomia intitulado Le grand dictionnarire de cuisine.

Sua narrativa é constituída de um elenco de reclamações e estranhamentos. Seu estômago não consegue se entender com o garbanzo (grão-de-bico). Critica a miscelânea que acredita representar o puchero. No final decide cozinhar sua própria comida:

\begin{abstract}
La cena se componía de una sopa al alzafrán, de un puchero y de un plato de garbanzos. La sopa al azafrán era una de las mejores sopas que haya comido, aunque tengo la sospecha de que estaba hecha con carne de oveja y no de vaca. Le recomiendo pues la sopa al azafrán. Como ve, digo tanto lo bueno como lo malo. Después venía el puchero, manjar esencialmente español: por lo demás, en su calidad de alimento nacional, constituye por sí mismo casi toda la cena española. Ay de usted, Madame, si no aprecia el puchero! Familiarícese, pues, poco a poco, con este plato y permítame, para facilitar el trabajo, decirle de qué se compone.
\end{abstract}

Se compone de un cuarto de vaca - en España, desde el punto de vista de la alimentación, el buey parece ser completamente desconocido -, un trozo de oveja, una gallina y lonjas de una salsicha llamada chorizo; todo esto se acompaña con panceta, jamón, tomates, azafrán y repollo. Es, como se ve, una macedonia de cosas bastante buenas si se las toma por separado, pelo cuya reunión me pareció desafortunada al punto de no haber podido jamás habituarme a ella. Procure hacer mejor que yo, Madame, pues si no le gusta el puchero, se verá obligada a contentarse con los garbanzos.

Los garbanzos son alubias del tamaño de una bala de calibre. Se trata, según creo, de lo que los antiguos denominaban "pois chiche", y de lo que Cicerón, de memoria elocuente, llevaba una muestra en la punta de la nariz. Desconozco el efecto que el garbanzo producía en la punta de la nariz de Cicerón, pero conozco el que produce en mi estómago, que no está nada habituado a ellos. Habitúese pues, Madame, a los garbanzos, como se habituará al puchero. Es fácil, comerá uno del primero día, dos el segundo, tres el tercero $y$, con estas precauciones, es probable que sobreviva a ellos.

Apurémonos a agregar que esta cena estaba servida con la más exquisita pulcritud por sirvientas del lugar, que lucian como damas de honor, y por las hijas de la casa, que lucian como princesas. Esta comida nos inspiró la firme resolución de preparar, en adelante, siempre que fuera posible, nuestra propia comida. ${ }^{16}$

Dumas, que a esta altura já era um escritor célebre, só frequentou o casamento real, a embaixada e no máximo o restaurante Lhardy, que aliás deplorou, com direito a zombaria escrita e lançada a Théophile Gautier. Nem esse restaurante afrancesado ou "franco-espanhol" ou "hispano-francês" conseguiu cumprir as demandas de requinte de Dumas:

Todos nuestros compañeros van a cenar a lo de Lardi, conducidos por Téophile Gautier, a quien encontraron vagando por las calles y que presumió de conocer España mejor que los españoles. Por lo tanto les predijo que cenarian muy mal. ${ }^{17}$

Ainda reitera em outra passagem seu descontentamento com o Lhardy, acreditando que fosse de um italiano. Aproveita também para reclamar do serviço quanto ao chocolate, bebida que ele aprecia, mas considera a quantidade absurdamente mesquinha:

Es bueno que le diga, Madame, que los españoles toman su chocolate en dedales. 
En cuanto a la cena, monsier Monnier nos había indicado un restaurante italiano, llamado Lardi [sic], en el que debíamos encontrar una comida honrosa. En Italia, donde se come mal, los buenos restaurantes son franceses; en España, donde no se come en absoluto, los buenos restaurantes son italianos. ${ }^{18}$

18

DUMAS, Alexandre. Op. Cit., p. 72.

19

BESAS, Peter. Op. Cit., p. 170 e177.

20

DUMAS, Alexandre. Op. Cit., p.157.

21

Pierre Jules Théophile Gautier (Tarbes, 1811 Paris, 1872). Escritor, poeta e crítico literário. Dentre a vasta obra é autor de 0 Clube dos Haxixins.

22

Charles Baudelaire dedica sua obra mestra, As Flores do Mal, a Gautier: "Ao poeta impecável/ ao perfeito mágico das letras francesas/ a meu caríssimo e veneradíssimo mestre e amigo THÉOPHILE GAUTIER/ com os sentimentos da mais profunda humildade/dedico estas flores doentias." BAUDELAIRE, Charles. As Flores do Mal. Rio de Janeiro: Nova Fronteira, 1985. p. 97.
Mal sabia Dumas, que se dizia muito iniciado em assuntos culinários, que o Lhardy era de propriedade de um conterrâneo. Foi Casimir Monnier, um livreiro francês que alojou a caravana do escritor, quem recomendou 0 estabelecimento. 0 Lhardy, localizado na Carrera San Jeronimo, n. 12, foi o primeiro restaurante aberto na cidade de Madri. Seu fundador era um francês de pais suiços, Émile Huguenin, que estudou pastelaria em Besançon e trabalhou como cozinheiro em Paris. Há indícios inclusive de que foi Prósper Merimée quem sugeriu a Huguenin que abrisse uma casa na capital espanhola. 0 nome Lhardy é, provavelmente, uma alusão a um restaurante parisiense inaugurado em 1795 no Bolevard des Italiens chamado Café Hardy.

Tratava-se de um estabelecimento extremamente "afrancesado". Mas nem o Lhardy agradava os franceses. Buscavam comida parisiense "pura", sem contaminações espanholas, que eles chamam de comida "franco-espanhola". Serviam vol-au-vents e consommés, é certo. Mas o senão ficava por conta do vinho nacional e do cheiro do alho e do azeite, sempre a assombrar os amantes da manteiga. ${ }^{19}$

As peripécias de Dumas pelas cozinhas madrilenas passam de uma crítica gastronômica ao puchero até a quase extorsão (a partir da pressão exercida por fuzis) de costeletas de carneiro, batatas e uma omelete gigante, que eram oferecidas a hóspedes ingleses na Posada de Calisto Burquillos, localizada nos arredores da capital:

Las costillas seguian cocinándose.

-Una sartén y una cacerola - pedí. Achard se apoderó de una sartén, y Giraud de una cacerola. Maestre Calisto Burguillos nos miró hacer estupefacto; pero como era uno contra ocho, y no tenía más arma que un cucharón contra cinco fusiles, no había modo de resistir.

Por un instante había tenido la idea de llamar a los ingleses en su ayuda; pero era un hombre bien instruido el maestre Calisto, y recordó que, en la guerra de la Península, los españoles padecieron más a causa de los ingleses, sus aliados, que de sus enemigos los franceses. De modo que se decidió a conservarlos en su casa a título de huéspedes solamente. $^{20}$

Foi com essa receptividade que Dumas se atracou com os sabores capitalinos. Fez questão de deixar muito claro que considerava que a comida e a bebida servidos ali não estavam a altura do "conforto", "luxo" e o "joy de vivre" das grandes capitais centro-europeias. Alimentar-se em Madri significava aventura, tormento e quase uma operação de guerra.

\section{Em busca do narguilé perdido: Theóphile Gautier}

Um dos mais célebres visitantes de Madri do XIX foi Theóphile Gautier $^{21}$, esse dândi mágico e engenhoso obcecado por haxixe e para quem Charles Baudelaire dedicou suas flores doentias ${ }^{22}$. Seu livro sobre a viagem à Espanha de pronto tornou-se guia para os viajantes franceses. 
23

Série de conflitos ocorridos no decorrer do século XIX na Espanha, entre os Carlistas, partidários de Carlos Isidro de Bourbon e sua sobrinha, Isabel da Espanha.

24

BESAS, Peter. Op. Cit., p. 157 e 162.

\section{5}

VAZQUEZ MONTALBAN, M. Un Teófilo Gautier inédito. In: GAUTIER, Teófilo. Viaje por España. Op.Cit., p.117

26

GAUTIER, Teófilo. Viaje por España. Barcelona: Mateu, 1971. p. 117.
Os motivos que levaram Gautier a esse país vão além de seus interesses pessoais e artísticos, influenciados pela leitura de uma Espanha romântica tracejada por Vitor Hugo em Os Orientais e dos escritos de Prosper Merimée. Por ocasião de sua primeira viagem, acompanhou seu amigo, Eugène Piot, que era colecionador de livros antigos e obras de arte. No ano de 1840, com a aproximação do fim da Guerra Carlista ${ }^{23}$ e a secularização de conventos em 1836, os dois pensaram que seria um bom momento para angariar acervos que haviam saído do mercado.

Gautier chegou em Madri em 22 de maio de 1840, por diligência. Juntamente com Piot, se instalou na Fonda de la Amistad, localizada na calle del Caballero de Gracia, administrada por um francês. Em outubro de 1846 volta a Madri, desta feita para cobrir o mesmo matrimônio de que fora incumbido Dumas, também enviado como correspondente do periódico La Presse. ${ }^{24}$

A brincadeira de Dumas relatada anteriormente, de que Gautier presumia conhecer a Espanha melhor que os espanhóis, não é de todo vã. Gautier era hispanista becado pelo Instituto de Cultura Hispânica. Escreveu o original desse livro, Viaje por España, obviamente em sua língua materna, mas é bastante emblemático que tenha mantido muitas palavras grafadas em castelhano, como se a sua tradução significasse uma perda. No campo da comida e da bebida o vocabulário mantido é grande, entre puchero, garbanzos e horchata de chufas.

Não vou aqui me adentrar nos caminhos literários, mas assim como Merimée, depois de seus relatos de viagem e de volta à nave mãe francesa, também escreveu ficções baseadas em suas impressões de Espanha. É o caso de Casilda Hijinosa, mal-casada de Sevilha que refogou sua sogra com direito a saboroso molho de salsa e pimenta como finalização. ${ }^{25}$ Nota-se aí, de um lado, uma fantasia enrustida de qualquer mulher que tenha lhe cruzado o caminho, e de outro uma leitura imaginativa e exótica do ser espanhol.

Gautier chegou a passear por bairros populares como El Rastro e sem dúvida se horrorizou com a "pobreza" das pessoas nas ruas:

Un dia, recorriendo el Rastro, el Templo de Madrid, después de haber saltado por encima de gran número de pordioseros que dormían tendidos en el suelo en medio de horribles andrajos, me encontré en una callejuela desierta. ${ }^{26}$

No que diz respeito aos líquidos, Gautier se encontra com os refrescos, água tomada com azucarillos, porosos de açúcar, às vezes acompanhados de laranja e limão. Escreve também sobre os cafés e botillerías da Calle de Alcalá, que segundo sua impressão são verdadeiros "tabernuchos" perto dos cafés parisienses. Mais uma vez é perceptível a sombra da cidade - mãe e a expectativa de encontrar sua própria casa:

Los cafés de Madrid nos parecen verdaderos tabernuchos, acostumbrados al lujo deslumbrador y mágico de los de París; la manera en cómo están decorados recuerdan mucho las barracas en que se exhiben las mujeres barbudas y las sirenas vivas; pero la falta de lujo está compensada cumplidamente con la excelencia y la variedad de los refrescos que en ellos se sirven. ${ }^{27}$

Apesar de seu repúdio em relação à "pobreza" do ambiente decorativo, percebe-se que Gautier circula um pouco mais pelas lojas de bebidas, se deliciando com horchata de chufa (suco elaborado com uma espécie de 
28

Ibidem, p. 120.

29

Ibidem, p. 125

30

GAUTIER, Teófilo. 0p. Cit., p. 126.

31 GAUTIER, Teófilo. 0p. Cit., p. 135

32

VAZQUEZ MONTALBAN, M. Op. Cit., p. 13. amêndoa, a chufa), o agraz (bebida feita com uvas verdes), sorvetes, cafés, mas sobretudo as cervejas de Santa Barbara com limão e o vinho Jerez, degustado pelas lojas de bebidas, de "pureza de neve", segundo o escritor. ${ }^{28}$

Embora de maneira bem mais diminuta e desatenciosa do que a minúcia com que detalha os cafés, Gautier implica com as tabernas que ofereciam jogos de bilhar, mas também descreve alguns ambientes mais populares como Tiendas de Vinos, onde provou Valdepeñas e vinhos licorosos:

\begin{abstract}
Una cosa verdaderamente sorprendente es la frecuencia de inscripción 'Juego de billar', que se ve repetida a cada veinte pasos. No os vayáis a figurar que estas tres palabras sacramentales tienen algo de misterioso; son sencillamente el anuncio donde se juega al billar. No me explico para qué demonios pueden servir tantos billares; el universo entero podría jugar su partida. Después de los juegos de billar, el anuncio más frecuente es 'Despacho de vino'. Alli se vende Valdepeñas y vinos generosos. Los mostradores están pintados con colores brillantes y adornados de colgaduras y ramajes. $^{29}$
\end{abstract}

Nota-se que Gautier se deu muito bem com os líquidos madrilenos, mas, assim como Dumas, ataca o puchero. De maneira mordaz e impiedosa, o escritor utiliza esse prato como critério inverso de civilização: "Los civilizados no saben hacer un puchero, ni una estera, ni un arnés. ${ }^{130}$

Impressiona-se vivamente com Goya, sobretudo com a tela El Tres de Maio, cuja pauta é o conflito entre franceses e espanhóis que se dá em Madri durante a Guerra da Independência, também chamada de Guerra da Península, a mesma citada por Dumas, por ocasião das ameaças ao cozinheiro espanhol que servia os ingleses:

Con una cuchara a guisa de pincel ejecutó una escena del Dos de Mayo, en la que se ven varios franceses que están fusilando a unos españoles. Es una obra de un nervio y de un carácter increibles. ${ }^{31}$

Mas os relatos de viagem de Gautier e sua busca pelos espelhos parisienses sem dúvida alguma reiteram uma crença por parte da Europa que se auto intitula "essencial" em relação à Europa marginal, a saber: a África começa ao sul dos Pirineus..$^{32}$ Essa questão permeia a leitura desses viajantes franceses do século XIX e certamente expressa a concepção de uma Europa periférica, e óbvio, a Espanha aí inclusa.

Vale lembrar que a noção de fronteira é uma construção cultural. Para uns, o Oceano Atlântico pode ser limite; para outros, caminho e passagem. Do mesmo modo, o sol e o vento escaldantes que pairam sobre a lbéria são indícios de pertencimento ao mundo africano e não uma extensão europeia. Entre parisienses e madrilenos as divisas parecem estabelecidas entre 0 azeite e a manteiga.

Tabacos, touros, naipes e vinhos: Jean-Charles Davillier

No livro Viaje a España, os relatos escritos são de Jean-Charles Davillier $^{33}$, um estudioso apaixonado por cerâmica, o que despertou seu interesse pela Espanha, pais que visitou em muitas ocasiões. Seu companheiro de viagem, Gustave Doré34 ${ }^{4}$ grande desenhista e litógrafo, há muito ansiava visitar o país pois já alimentava projeto de ilustrar Dom Quixote de Cervan- 
33

Ruan, 1823 - Paris, 1883.

34

Paul Gustave Doré (Estrasburgo, 1832 - Paris, 1883).

35

Paris, 1631-Chantilly, 1671.

36

DAVILLIER, Barón Ch.; DORÉ, Gustavo. Viaje por España. Madrid: Adalia, 1984. v. 1, p. 16.

37

Toma-se como Mesa Redonda o modo de servir comida e bebida no XIX na Espanha: todos se serviam numa mesma mesa e num mesmo turno, onde se servia um menu igual a preço fixo. BESAS, Peter. Op. Cit., p. 20.

38

Ibidem, v. 2. p. 186.

39

BESAS, Peter. Op. Cit., p. 214.

40

Ibidem, p. 215. tes e para tanto, carecia de inspiração in loco. No decorrer da jornada Doré visualiza e ilustra os relatos de Davillier.

Mais uma vez percebe-se uma atitude de procurar a França, a sua origem, no outro. Nessa passagem emblemática, Davillier pondera que a Península ainda está a espera de um seu François Vate ${ }^{35}$, cozinheiro da aristocracia e da realeza, inventor do creme de chantilly, que deu cabo de sua própria vida por conta da tragédia do atraso da entrega do peixe que utilizaria para um jantar:

\begin{abstract}
La Península, que cuenta con tantos grandes hombres, no ha producido un gran cocinero y espera aún a su Vatel. Sancho Panza, glotón por naturaleza, se alababa de resistir una semana entera con un puñado de nueces o de bellotas. En lo que a nosotros se refiere, poco preocupados por el asunto gastronómico, estamos decididos a recibir las cosas como vengan, siguiendo el ejemplo de este gran filósofo. ${ }^{36}$
\end{abstract}

0 autor ainda atira em direção a Sancho Panza, representante do populacho, acusado de uma falta de seletividade, ao comer bellotas, comida que tradicionalmente é distribuida aos porcos criados para produção do jamón. Antes esses viajantes fossem tão receptivos e dados a novos sabores e aventuras tal qual o desobediente Panza.

Uma vez que chegaram em Madri, Davillier e Doré hospedaram -se na Fonda de París, onde pagaram por uma habitação única no primeiro piso 0 preço de cento e vinte reales, incluindo a mesa redonda ${ }^{37}$ do hotel a disposição, embora não tenham utilizado os serviços porque todos os dias eram convidados a comer e beber em casa de amigos. Segundo Daviller o quarto em que se instalaram dava para a Calle de Alcalá e era muito ordinário. ${ }^{38}$

Davillier se refere, desta feita com um tom bem menos crítico, aos estabelecimentos dos bairros que ele denomina "mais elegantes", que vendem horchata de chufa no verão, às vezes misturada com água de cevada.

Escritor e desenhista adentraram os bairros mais populares de Madri, repleto de posadas e tabernas. 0 escritor também lança um olhar bastante ácido em relação a esses estabelecimentos:

Dejemos la calle Mayor para ir a la de Toledo.[.... No lejos de aqui, en la calle de Segovia, están los mesones donde se alojan los arrieros y las gentes del pueblo que llegan de las provincias. Es preciso admitir que estas posadas no han progresado desde los tiempos de Don Quijote, y su aspecto no puede ser menos atrayente. ${ }^{39}$

A visão do escritor é extremamente pejorativa, relatando cenas "pitorescas", de uma multidão perigosa repleta de barbeiros, criaturas vendendo de tudo pelas ruas, de água a carvão, hortaliças, frutas, castanhas, todos gritando como num pregão e comportando-se como uma manada de asnos. ${ }^{40}$

Mas a sua maior repulsa Davillier reserva ao bairro do El Rastro, que em meio a uma fábrica de tabaco, é um reduto de tabernas, recheadas de ladrões em busca de vinho e comida ruins, um gueto de sujeira e miséria, frequentado por gente da pior espécie, segundo sua mirada:

Arriesguémonos ahora en el Rastro, la parte más sucia de todo Madrid, que recuerda a la vez al Temple, a la plaza Maubert y a la antigua Cité. El Rastro es el barrio del 
41 Ibidem, p. 216.

42 BESAS, Peter. Op. Cit., p. 218.

43

Ibidem, p. 259.

44

Ibidem, p. 168.

45

BESAS, Peter. Op. Cit., p. 362.

46

MERIMÉE, Prosper. Op. Cit., p. 227 e 274. vicio y le la miseria, la residencia de los revendedores, traperos y chatarreros. Los prestamistas son aquí aún más numerosos que en el resto de la ciudad, que no es decir poco! A cada paso vemos un Despacho de vino, donde se vende el vino en botas y en cantaros de barro, o bien una taberna cuya cocina, poco apetitosa, recuerda los arlequins de algunas zahúrdas de París. Estas 'ermitas de Baco', según expresión de Cervantes, se ven frecuentadas por una población achacosa y mal vestida, parte de la cual pertenece al gremio de los ladrones, numeroso y temible aquí, como en todas las grandes ciudades, y que se llama en germanía la cherinola. ${ }^{41}$

Na mesma página sentencia Davillier: "Tabaco, toros, naipes y vino. Levan al hombre a San Bernardino", referindo-se a uma fábrica de tabaco localizada nesse bairro, aos jogos e vinho consumidos nas tabernas e ao hospício San Bernardino para pobres existente em Madri, fado certo dos que usufruem de todas as alternativas anteriores. ${ }^{42}$

\section{Vinho detestável, mulheres que dormem com cebolas na boca: Prosper Merimée}

Prosper Merimée nasceu em Paris no ano de 1803. Seu pai era um pintor de certa reputação e sua mãe procedia de uma família versada em literatura e artes. A Espanha sempre o fascinou e esteve sete vezes neste país entre os anos de 1830 e 1864. De todas essas experiências deixou vasta documentação epistolar. Essa compilação que encontrei em Madri foi organizada, traduzida e comentada por Gabino Ramos de Gonzalez. Muitas dessas cartas são endereçadas a Sra. De Montijo, uma andaluza que tornou-se sua grande amiga e confidente.

Merimée, como os demais escritores abordados, segue para a Espanha na saga por impressões intensas, mas o resultado é um misto de enamoramento com resmunguice em relação aos hábitos locais. Sua leitura tem algumas especificidades, como sua crença na superioridade das classes populares em detrimento das mais elevadas:

Hay entre la canalla una elevación de sentimientos y una cortesia natural que me encantan y me atraen tanto cuanto me repelen y aburren los convencionalismos de los salones. ${ }^{43}$

Também admira a prodigalidade dos madrilenos, considerando-os uma aula de sinceridade e autenticidade:

Aquí se piensa en voz alta y no se sienten cohibidos por casi nadie. Se tiene una franqueza que a nosotros los franceses nos sorprende mucho, y que me asombra tanto más cuanto que usted me ha acostumbrado a algo muy distinto. Debería ir a darse una vuelta allende los Pirineos para tomar una lección de veracidad. ${ }^{44}$

Entretanto, faz coro quanto aos protestos contra as hospedarias que considera ruins e cheias pulgas. ${ }^{45}$ No mais, não é perceptível em seus escritos muita empolgação pelo comer e beber de Madri. É certo que se encrespou com Dumas e suas críticas publicadas em De París a Cádiz, em relação ao tamanho dos copos com que se servia chocolate. Sobre o puchero, verdadeira obsessão temática entre os escritores românticos do XIX, relata que comeu acompanhado de garbanzos, mas laconicamente, sem tecer grandes descrições e o mesmo ocorre sobre os pimentões. ${ }^{46}$ Por várias vezes afirma que a 
47

Ibidem, p. 292

48

Ibidem, p. 338

49

Ibidem, p. 334

50

Ibidem, p. 226.

51

MERIMÉE, Prosper. Op. Cit., p. 361.

52

Ibidem, p. 255 comida não lhe agrada, que desejaria ser servido com pescado e carne todos os dias. ${ }^{47}$ Em sua última estadia em Madri, no ano de 1864, relata: "La cocina es tan mala y el chocolate tan bueno como antaño."48 Confessa saudades do chocolate, mas reitera suas objeções em relação à comida de uma maneira geral. Dá-se a impressão, até por sua peleja com Dumas, que essa bebida espessa de cacau foi uma das poucas coisas que Merimée gostou de colocar na boca na capital espanhola.

Uma das únicas vezes em que avalia a força dos condimentos, como o alho e pimentão, Merimée os considera como um perigo à saúde, como quando comeu em casa de seu amigo Calderón e descreve com argúcia o que parece se assemelhar a uma paella:

Dos platos inmensos de sopa de arroz en la que hay de todo: carne, mariscos, etc., y pescado, con una salsa horrible hecha con ajo y pimentón (que me hizo estar sediento por toda la noche) y otros veinte platos por el estilo. Me presentó a la cocinera, que es menudita de cuerpo, con cara muy sonriente, muy redonda y tan rellena como un pudin. Realmente tiene un gran talento, pero pronto matará a su amo. ${ }^{49}$

Também não parece ter se dado muito bem com os álcoois. Considera o vinho da terra tão forte como aguardente..$^{50}$ Do que se bebe em Madri, ironiza supostas falsificações e afirma que um grupo bem seleto toma manzanilla, o que parece ser fantasioso.

El vino que se bebe en Madrid es inimaginable. No hablo del burdeos y del champán, fabricados - creo - con sustancias muy ajenas a la vid, sino del vino de Jerez. Es detestable. El único potable es la manzanilla; pero sólo la bebemos los andaluces, las putas y yo. ${ }^{51}$

Também não faltam estereótipos sobre as mulheres e o que são capazes de fazer com a boca e alguns tipos de alimentos. De Madri escreve: "Hay aqui uma viuda andaluza guapa, que tiene toda clase de atractivos, y que dice: 'como eztá uzté', que al acostarse se pone cebolla en los labios 'pá que zean maz frescos'."52

A escrita de Carmen, bem como as ilustrações de Doré feitas para a edição de Dom Quixote são desdobramentos criativos que foram elaborados a partir dos relatos e impressões. Sua força espalhou por toda a Europa a visão de uma Espanha exótica. Evidente que Carmen, obra ficcional, não pode ser vista no mesmo prisma que um relato de viagem. Mas trata-se de uma leitura sintese dos hábitos espanhóis observados no raconto de várias viagens que Merimée fez à Espanha. Não vou analisar aqui o estereótipo do sangue destemperado na literatura de Merimée, da imagem construída da mulher que carrega uma navalha escondida na cinta-liga, que durante a noite soca ovos moles na parede por um homem e no dia seguinte atravessa a rua para não cruzar com seu rosto. Carmen é um mito, uma Medéia espanhola. Mas o que é interessante ponderar é que, nesta obra- talvez porque Merimée tenha de fato tentado penetrar na Espanha com sua paixão, suas sucessivas viagens e o domínio da língua castelhana -, a taberna é o lugar onde tudo acontece. A cena da taberna é a mais importante de Carmen: é onde se consumam as desavenças, declara-se o amor, reúnem-se os contrabandistas, os personagens tiram suas máscaras e dizem a que vieram e quem são. 
53

Edmundo De Amicis, (Oneglia, 21 de outubro de 1846 - Bordighera, 11 de março de 1908).

54

DE AMICIS, Edmundo. España. Viaje durante el Reinado de Don Amadeo I. Madrid: Librería de Vicente Lopes, 1883.p. 132.

55

DE AMICIS, Edmundo. Op. Cit., p. 134-135.
0 lado avesso da lenda negra: De Amicis

0 notório Alexandre Dumas sequer entrou numa taberna de Madri - e se entrou, não contou para ninguém. Gautier atravessou sua soleira e provou Valdepeñas e vinhos generosos, mas se encastoou com os jogos de bilhar. Davillier não parece ter ficado bem impressionado com o reduto de tabernas de El Rastro. Quanto a Merimée, talvez nunca saberemos se sua cena de taberna em Carmen é fruto tão somente de sua imaginação.

E não faltou quem criticasse de maneira corrosiva as exigências desses viajantes famosos. Edmundo De Amicis ${ }^{53}$ foi à Espanha no ano de 1871 e percorreu boa parte do país em cinco meses de viagem. Não há dúvida de que este escritor italiano coloca um olhar muito mais benevolente e afetivo, chegando a defender a lbéria dos impropérios desferidos pelos franceses.

$\mathrm{Na}$ altura dessa segunda edição espanhola a que tive acesso, datada de 1883 e traduzida diretamente do italiano por Augusto Suarez de Figueroa, esse livro já havia sido publicado na Alemanha, Inglaterra, França e Áustria.

É incrivel como esse relato é quase uma carta-resposta aos outros vistos até aqui. De Amicis atenta para que o viajante tem de abrir o olho para penetrar na língua e na cultura locais. ${ }^{54}$

Sobre o consumo de comida e vinho, De Amicis elabora uma leitura bem distinta dos demais autores abordados a propósito do puchero, tão ofendido sobretudo pela inserção dos garbanzos, talvez por sua remetência moura. Ironicamente, o garbanzo é parte cultural do mesmo orientalismo que causava tanto frisson entre os escritores românticos. E ao invés de considerar o prato uma miscelânea tresloucada, como classificou Dumas, De Amicis reputa-Ihe estatuto de antologia culinária. Aproveita inclusive, para alfinetar os franceses, que considera crianças mimadas, e em especial aos queixumes de Alexandre Dumas:

\footnotetext{
Los franceses, que en punto á comer son quisquillosos como muchachos mal acostumbrados, dicen pestes; Alejandro Dumas afirma que ha padecido hambre en España; y un libro sobre este país, que tengo á la vista, sostiene que los españoles no viven más que de miel, hongos, uvas y legumbres. Son tonterías. [....] Además, su puchero, [...] lo devoraba con rosiniana glotonería. El puchero es, respecto al arte culinaria, lo que es respecto á la literatura una antología: hay un poco de todo, y do lo mejor. Una buena tajada de vaca hervida forma como el número del plato; alrededor un ala de pollo, un pedazo de chorizo (el chorizo con prodigalidad), yerbas y pernil; encima, debajo, y en todos los intersticios, garbanzos.[...] Un buen puchero y una botella de Valdepeñas pueden bastar á cualquiera. ${ }^{55}$
}

Outro ponto interessante é que onde os demais viajantes viram impertinência para receber e servir (com exceção de Merimée), De Amicis enxerga uma atitude de altivez. No campo da hospitalidade desmente completamente a petulância que os demais disseram encontrar e entende as pessoas como discretas, afetivas e sinceras:

\footnotetext{
Y luego tienen maneras francas y gentiles; acaso menos finas, pero en realidad más amablemente ingénuas que aquellas por que son tan loados los franceses. En vez de dirigiros una sonrisa, os alargan un cigarro; en vez de deciros un cumplido, os estrechan la mano; y son más hospitalarios en obras que en ofertas.[...] El pueblo tiene su saludo afectuoso de - Vaya V. con Dios,- que vale más que todos los besos en las manos. ${ }^{56}$
}

Essa busca por uma atitude serviçal - comportamento que não é típico 
BLACKBURN, Henry. Travelling in Spain in the Present Day. Londres: Sampson Low, Son \& Marston, 1866. p. 36-50.

59

Leia-se: sem alho e azeite.

60

SANTOS, Carlos Roberto Antunes. A alimentação e seu lugar na história: os tempos da memória gustativa. História: Questões \& Debates, Curitiba, n. 42, p. 11-31. 2005. da cultura espanhola - é uma conduta bastante perceptível nesses viajantes abordados, entre outros. Southern (inglês de classe alta), na procura de casas de hóspedes, tenta se acostumar com o que ouve quando bate nas portas em busca de informação: "Quién es usted?" e "Qué quiere usted?"57

0 britânico Henry Blackburn, secretário de um deputado parlamentar, que passou outono e inverno de 1864 na Espanha, hospedou-se na fonda de los Principes, na Puerta del Sol. Queixa-se do vinho, que considerava muito forte. Já o serviço, foi avaliado como "muito espanhol". Traduz essa última expressão com língua envenenada: "En España todos son contrariedades".58

Em suma, esses escritores cultos, todos advindos de uma classe média ou alta, supunham que suas respectivas "civilizações" eram extremamente sofisticadas e propensas ao conforto.

Entretanto, esse suposto olhar refinado pode também ser visto como um limite de abertura das culturas centro europeias em entender o outro, com diferentes costumes e maneiras de interagir. Esses viajantes queriam encontrar na Espanha a reprodução de seu habitat natural e não um outro mundo por desvendar.

Lamentam-se com a sujeira, a falta de móveis, a promiscuidade dos lugares para dormir, comer, beber, da saga pela busca da comida "não espanhola"59, da ranhetice dos serviços, mas são abrigados nas casas particulares, singularidade da hospitalidade ibérica vista de maneira equivocada pelos estrangeiros. Também não entendem muito bem sobre os lugares para comer: eles buscam a brasserie e o restaurant, a "cultura gastronômica parisiense". No contraponto, como se verá adiante, existe toda uma resistência em Madri em relação à imposição da culinária francesa no que diz respeito à cultura popular.

Como já foi colocado, comida e bebida é cultura, envolvendo heranças e recusas. Os franceses ficavam apavorados com os cérebros fritos, manitas de porco, as misturas do puchero, os garbanzos, a força alquímica do alho com o azeite. E por outro lado, a busca de sofisticações do cardápio francês não corresponde à elegância simples da comida ibérica.

No mais, a ojeriza ao uso do azeite e do alho, enquanto elementos mal cheirosos e indigestos, sobreviveu em algumas regiões europeias até a década de 1960. Levando em conta essas passagens, bem como a alta moda da cozinha mediterrânea atual, pode-se remeter a uma história das mudanças do gosto, de novos elementos que ora são objetos de repulsas e ora são abraçados.

A história da mesa, do que se come e bebe, pode ser vista como microcosmo da sociedade e inserida no campo da história dos sentidos e da sociabilidade ${ }^{60}$, em que vigoram saberes acumulados, trocas culturais, pelejas e perdas. Quem já não se sentiu arrebatado ou coagido por meio de um sabor?

Sorver não é tão somente um gesto nutricional. Se fosse esse o caso quando falo de memória gustativa estaria narrando uma história da língua e desprezando toda a larga dimensão social e cultural que envolve condutas, hábitos, costumes e herança afetiva.

Virando a mesa, o confronto com a leitura de um cronista madrileno: Enrique Sepúlveda

Não há dúvida de que Dumas, Gautier, Davillier e Merimée hegemonizam uma visão do comer, beber e receber que vem de fora, desenhando uma lenda negra estereotipada sobre o puchero, o vinho, as casas de comida, 0 ambiente e entornos das tabernas de Madri. ${ }^{61}$ 
61

DÍAZ, Lorenzo. Diez siglos de cocina en Madrid: de los mesones de ayer a los restaurantes de hoy. Barcelona: Folio, 1994. p. 77.

62

SEPÚLVEDA, Enrique. La vida en Madrid en 1886. Madrid: Librería de Fernando Fé, 1887. p. 463.

63

SEPÚLVEDA, Enrique. La vida en Madrid en 1886. Op. Cit., p. 464.

64

Ibidem, p. 489.
Lógico que considera-se aqui que ocorre uma percepção plural de um mesmo espaço que não é uniforme nem linear, com forte contraste entre os viajantes ilustrados (provavelmente mais incitados e atraídos pelos jardins botânicos, museus de arte e científicos, como é o complexo que envolve o Paseo Del Prado do que se engalfinhar entre tipos pouco célebres numa taberna) e uma leitura popular da sociabilidade que esses escritores apenas resvalaram e com olhar bastante enviesado.

Um contraponto a esse parisinismo que os viajantes procuravam em Madri é o cronista Enrique Sepúlveda, extremamente envolvido com o que se denominou Costumbrismo. Esse movimento, inicialmente associado à Espanha nos séculos XVIII e XIX, espalhou-se por todos os paises de língua castelhana da América. A proposta era a interpretação literária ou pictórica da vida cotidiana e local, seus costumes e hábitos. Quando não assume um tom satírico, pode perpassar para uma abordagem dos detalhes folclóricos, muitas vezes tendendo para uma romantização. Muitos foram os costumbristas espanhóis que, juntamente com Enrique Sepúlveda, escreveram crônicas de modalidade descritiva no meio literário da segunda metade do XIX, como: Carlos Frontaura, Eusebio Blasco, Ramón de Navarrete, Nacís Oller e Sabino de Goicochea.

0 conjunto de textos que acessei é constituído de crônicas reunidas em livros: La Vida en Madrid en 1886 e A Vida en Madrid en 1888. Há um artigo de nome Diners Lhardy em que Enrique aponta para o afrancesamento presente nesse estabelecimento ao registrar um menu do restaurant, datado de 18 de novembro de 1886, constituído de comida francesa com um toque espanhol quase inaudito, talvez mais pela presença do Jerez como vestígio:

Puré Chasseur; Consomme; Aguiles financieres; Roast-beef aux legumes; Apies Langostinos; Petit pois a I'anglaise; Dessert; Vins; Jerez, Saint -Julien; Champagne. ${ }^{62}$

Com esse cardápio, segundo Sepúlveda o Lhardy cravou a insígnia em sua casa de reduto vacilante da geração de gourmets. ${ }^{63}$ No artigo A Taberna, a reclamação e correspondente ansiedade ficam mais explícitas numa altura do texto em que o escritor diz que o problema é que a taberna, vítima de modismos, agora dava para se disfarçar de café:

Pero si la taberna se ha vestido á la moda disfrazándose de café, el vino existe lo mismo con filoxera y fuschina, y mientras el jugo de Noé ó de la quimia vulgar están emboltellados ó empollegados (con perdón de la Academia) para alegrar á los mortales de este lado meridional del planeta, ha haber juergas y parrandas y borracheras de tomo y lomo. ${ }^{64}$

Não há dúvidas de que esta referência meridional, onde os mortais se divertem com juergas y parrandas y borracheras, é uma tomada de posição manifesta de situar-se ao sul dos Pirineus, assim como o receio do autor de que a tradição tabernal não viveria às contaminações da Europa do norte.

Já no artigo La vida moderna: La mesa - esse sim uma resposta a todas as ofensas atiradas ao cocido (ou puchero) -, Sepúlveda critica os costumes gastronômicos da nova burguesia madrilena que abandona pratos típicos em troca de expoentes da cozinha francesa:

En las mesas de nuestros personajes á la moda, no se sirve ya el cocido nacional 
SEPÚLVEDA, Enrique. La vida en Madrid en 1888. Madri: Libreria de Ricardo Fé, 1889. p. 143-148.

66

Idem, p. 148.

67

Filipe $V$ da Espanha foi o primeiro da dinastia Bourbon a governar Espanha, tendo iniciado seu reinado em 1700. Essa casa Real europeia foi derrubada e restaurada no pais por diversas vezes, tendo reinado de 1700 a 1808 , de 1813 a 1868 , de 1875 a 1931 e de 1975 até os dias atuais.

68

DÍAZ, Lorenzo. Madrid: bodegones, mesones, fondas y restaurantes. Cocina y sociedad (14121990). Madrid: Espasa Calpe. 1990. p. 232.

69

Tudo começou com um xeque-mate enviado por Napoleão Bonaparte aos reis de Portugal e Espanha. A disputa entre as revoluções industriais inglesa e francesa começou a adquirir uma maior dimensão quando cada uma das potências passou a se empenhar para que seu concorrente caísse privado de mercado. Durante um certo período Portugal fez jogo duplo ao acolher navios ingleses em seus portos e estabelecer comércio com países ligados à França. Em 1807 Napoleão enviou um ultimato a Lisboa para que fossem fechados os acessos à Grã-Bretanha. França e Espanha assinaram o Tratado de Fontainebleau, a partir do qual pactuavam que invadiriam juntos e repartiriam Portugal. 0 desfecho dessa tramóia nós bem conhecemos. Enquanto as tropas napoleônicas cruzam a Espanha para dirigir-se a Lisboa, o regente João embarcou com a família real, corte, arquivos e acervos de livros valiosos em direção ao Rio de Janeiro. Quando o general JeanAndoche Junot, a mando de Napoleão, chegou a Lisboa já era tarde: os Braganças não estavam mais na cidade, que tornou-se um satélite francês administrado por um militar. 0 sul de Portugal foi invadido pelos espanhóis, onde ficariam até 1808 , quando regressaram à Andaluzia para combater os franceses. Nesse mesmo ano o povo português enfrentou as tropas napoleônicas, sobretudo na cidade do Porto. Ingleses juntaram-se aos lusos e Junot capitulou. Na sequência, Napoleão envia tropas para o norte de Espanha com o pretexto de apoiar a ocupação em Portugal, e toma as cidades de Pamplona, Barcelona, Figueres e San Sebastian. 0 marechal Joaquim Murat marcha com cem mil soldados em direção a Madri. Antes de sua chegada, porém, uma rebelião em Aranjuez depõe o rei Carlos IV e afasta Manuel de Godoy (primeiro ministro e provável amante da rainha Maria Luisa de Parma). 0 principe das Astúrias assume o trono espanhol como Fernando VII, que recebe o marechal Murat como aliado, acreditando que Napoleão cumpriria o Tratado de Fontainebleau. Entretanto, Fernando VII é forçado a abdicar e reconhecer José Bonaparte, irmão de Napoleão, como rei da Espanha. LUCENA SAMORAL, Manuel. El siglo XIX: la utopía de libertad, orden y progreso. In:__ (org). Historia de Iberoamerica. Madri: Cátedra, 2008, p. 47-55. por considerarlo ordinario, aunque no haya dejado de ser higiénico, restaurador y suculento. Qué se diría de una dama castellana [que servisse o cozido], que era una 'provinciana' imposible de civilizar. Donde quiera que hay vergüenza nacional existe cocina propia.[...] Un inglés ha dicho que del cocido español se pueden hacer 'quince' platos sabrosos y alimenticios, es decir, toda una comida. Por qué, pues, poseyendo un arsenal de manjares tan interesantes e irreemplazables hemos de ser feudatarios del exótico 'menu' donde campean descaradamente los 'cannelones' á la Richelieu, las 'mauvistes' en 'croustade', el 'Rissoto', á la Regencia y los 'profiterolles' al 'chocolats'? Esto no tiene sentido común ni nada que lo justifique.

Si llega á perderse, como amenaza, el clásico cocido á la madrileña ó á la andaluza, no habrá quedado á nuestra raza ni siquiera el recuerdo de su pasada existencia culinaria, porque todo, todo será en nuestras casas francés: ropas, utensilios, muebles, manjares, vinos, refrescos, pastelería, confitería, y hasta el modo de hablar y de ... señalar.

Por piedad, señores de la vida moderna! Dejemos algo á la patria, aunque solo unas sopas de ajo y unos huevos (no artificiales) pasados por agua. ${ }^{65}$

Para finalizar a crônica, Sepúlveda conta que seus amigos vão comer no hotel e ele thes acompanha até o local do banquete. De pronto, vê surgir na porta o chefe do comedor que Ihes saúda: "Madame est servie." Resta a conclusão derradeira do contista: "Como progresamos!"66

\section{E o campo das disputas dá-se na mesa}

Enrique Sepúlveda não está ilhado. Se os viajantes achavam a comida e bebida capitalinas "muito espanholas", um bom contingente de madrilenos julgava que ela estava a se transmutar em francesa por demasia.

É preciso frisar que ocorre uma resistência da cozinha popular frente ao afrancesamento adotado pela aristocracia. As influências dos gostos galicistas invadem Madri juntamente com a corte dos primeiros Bourbons ${ }^{67}$, desfilando um festival de consommés e ragouts entre as altas rodas. Desde a segunda metade do século XVIII no palácio Real imperava a cozinha francesa, comportamento mimetizado pela nobreza e pela alta burguesia, cujo sonho de consumo era ter um chef aquartelado em sua despensa. ${ }^{68}$ Enquanto isso, a cozinha popular se levantará em armas, utilizando como munição açafrão e pimentões.

Para entender esse debate é necessário contextualizar, ainda que muito brevemente, a Guerra da Independência ou Guerra da Península (18071814), conflito inserido nas chamadas Guerras Napoleônicas. ${ }^{69}$

Como reação à ocupação de tropas francesas e à anulação da Casa Real Espanhola o povo de Madri realiza o levante de 2 de Maio de 1808, resistindo aos invasores com todas as suas entranhas, de primeiro amotinado no Palácio, e depois atacando os invasores em vários sítios da cidade, como Puerta del Sol e o Parque Monteleón. É nesse momento que essa sucessão episódica começa a interessar aqui. $E$ talvez aí clareie a irritação com a impertinência dos espanhóis frente aos viajantes, contestando, como relatou Southern, citado anteriormente: "Quién es usted?" y "Qué quiere usted?" E quem diria então da atitude de Dumas arrancando das bocas de hóspedes ingleses um pouco de vinho e costeletas na ponta de fuzis, em meio a um estabelecimento manchego, entranhando uma heroicização de si.

A consequência dessa batalha é a ordenação do marechal Murat (cunhado de Napoleão) pelo fuzilamento de milhares de espanhóis. Posteriormente Francisco Goya homenageou os resistentes em Os fuzilamentos 
70

LUCENA SAMORAL, Manuel. Op. Cit., p. 47-55.

71

REVILLA, Fidel; RAMOS, Rosalía. Historia Breve de Madrid. Madrid: Ediciones La Librería, 2012. p. 162-163.

\section{2}

LÓPEZ CARCELÉN, Pedro. Atlas Ilustrado de la historia de Madrid. Madrid: Ediciones La Librería. 2013. p. 50. de 3 de maio, que tanto impressionou Gautier em sua visita ao Museo Del Prado.

A França só seria derrotada no ano de 1814 pelos exércitos britânico, português e espanhol. ${ }^{70}$ Mas a saga com que a raia miúda madrilena enfrentou os franceses e a crueldade com que foi reprimida deixaram marcas pela cidade ainda visíveis em tempos recentes. Nos quase quatro anos em que José Bonaparte (nomeado Rei da Espanha durante o período da invasão) permanece em Madri, lança mão de uma picareta urbana. Derruba conventos (como das monjas carmelitas de Santa Ana e dos monges de San Norberto), cria e amplia praças (entre as quais Santa Ana, Mostenses, Oriente, de Las Cortes), propõe a retirada dos cemitérios (todos então localizados dentro ou ao lado das igrejas) para fora dos limites da cidade, tomando para si o discurso de busca de uma urbe com espaços livres, mais salubre e sã. ${ }^{71}$ Mas 0 populacho jamais o perdoaria, atribuindo-Ihe alcunhas de Rey Pepino e Pepe Botella (por sua fama de beberrão), entre outros codinomes pernósticos. ${ }^{72} \mathrm{~A}$ respeito desse último apelido, várias são as canções populares que desenvolvem o tema, como a copla de ciegos:

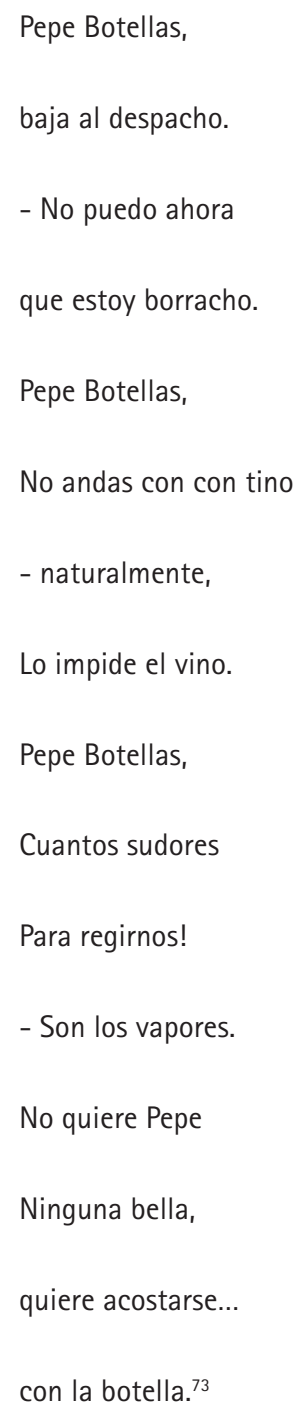

Essa reputação de borrachice é explicada por um episódio em que houve um recolhimento de vinho de Arganda e Chinchón pelas tabernas das calles de Toledo e Cebada por conta de uma suposta urgência de prover uma 
REVILLA, Fidel; RAMOS, Rosalía. Historia Breve de Madrid. Madri: Ediciones La Libreria, 2012. p. 163.

75

DÍAZ, Lorenzo. Madrid, tabernas, botillerias y cafés (1476-1991). Madrid: Espasa Calpe. 1991. p. 51-52.

76

Ibidem, p. 118.

77

Ibidem, p. 69.

78

Ibidem, p. 69.

79

MONTOLIÚ CAMPS, Pedro. Enciclopedia de Madrid. Barcelona: Planeta, 2002. p. 217.

80

Grupo que corresponde a 70\% da população da cidade de Madri, cuja renda constava de menos de 2 mil reales anuais. DÍAZ, Lorenzo Madrid, tabernas, botillerias y cafés. Op. Cit., p. 69.

81

DİAZ, Lorenzo. Madrid, tabernas, botillerías y cafés. Op. Cit., p. 69-70.

\section{2}

Ibidem, p. 71.

83

SEPÚLVEDA, Ricardo. Madrid Viejo: crónicas, avisos, costumbres, leyendas y descripciones. Madrid: Librería de Fernando, 1888. p. 349-350. expedição real durante uma viagem, sendo que todo o estoque havia sido roubado pela noite por "saqueadores" espanhóis. ${ }^{74}$

A Madri sob a administração de Rey Pepino assentava quatro cafés: La Fontana de Oro, del Ángel, San Luis e de la Cruz. Na calle Toledo organizam-se mercados onde vende-se especiarias de Extremadura, vinho manchego, frutas e toda sorte de comestiveis (ou não). Possuía cerca de $175.000^{75}$ habitantes e mais de $800^{76}$ tabernas, ou seja, uma por 220 pessoas.

Voltando à Guerra da Independência, uma de suas consequências duradouras é que a Espanha ficaria dividida entre os afrancesados, que apoiariam a ocupação, e a resistência. Por outro lado, o contexto do período que sucede o conflito traz à luz novas classes médias que, segundo Lorenzo Díaz, são bastante distintas do contexto atual:

\begin{abstract}
Y quien formaba esos nuevos estratos intermedios? El concepto de clase media actual no correspondía a la noción que se tenía entonces. Actualmente, el término se utiliza para referirse a la llamada pequeña burguesía, profesionales liberales y cuellos blancos en general. Antaño, en el siglo XIX, el concepto se utilizaba para designar a los que no pertenecian a la aristocracia ni al áspero mundo del trabajo manual en cualquiera de sus aspectos, tanto urbano como rural. Entonces esta clase media era una especie de mediocre burguesía conformada y gris. $^{77}$
\end{abstract}

0 cenário evidente para esses grupos seria 0 já descrito restaurante Lhardy, estabelecimento fundado e conduzido por um francês que buscou reproduzir o parisinismo em campo inimigo.

Lorenzo Díaz, em seu estudo, aponta para alguns alimentos de luxo consumidos pelas camadas mais abastadas do XIX, entre eles: pescado fresco (transportado de Bilbao), aguardente, açúcar, café, cacau, marzipã, mel, queijo, leite. ${ }^{78}$ Montoliú Camps também faz um inventário do que era servido nas mesas da aristocracia:

En las casas de los nobles, los principales platos también estaban formados por carne, ya que los malos caminos y la distancia a las costas impedian el consumo de pescado fresco, por lo que tenían que conformarse con pescado de rio, en especial truchas, junto a bacalao seco y salado. Ello no impedia que, en determinadas celebraciones, se consumieran meros, langostinos, atunes, langostas, pulpos y hasta sardinas, pero ello se lograba previa salazón de los productos o mediante su traslado dentro de cajones rellenos de nieve mezclada con paja. ${ }^{79}$

Por outro lado, destacam-se nas mesas e estabelecimentos frequentados pelos pobres ${ }^{80}$ : pão (de trigo ou uma mescla de cevada, centeio e outros grãos menos nobres), carne (sobretudo de cordeiro ou porco), azeite de oliva e garbanzos, cebola, alho e ovo fresco ${ }^{81}$ Não se pode deixar de aferir que tratam-se dos ingredientes principais do cocido (ou puchero), prato que era a dieta básica dos populares, como coloca Lorenzo Díaz:

Esta exigua dieta se concretaba en un desayuno de pan fresco, después de lo cual el pan sobrante y otros ingredientes se guisaban en un 'puchero'. Frio o caliente, dependiendo del precio del carbón, este puchero constituía tanto la comida como la cena. ${ }^{82}$

0 escritor Ricardo Sepúlveda reitera para o que se comia nas tabernas do XIX: cocido, sopa, carnes, garbanzos, vinho..$^{83}$ Enfim, segundo fontes variadas, o cocido - já na versão que tanto agredia os narizes e estômagos sensiveis dos franceses, composto de grão-de-bico, verduras, vaca, carneiro, pernil, galinha, chorizo, toucinho, orelha e pé de porco - era o prato popular: 
84

MONTOLIÚ CAMPS, Pedro. Op. Cit., 2002. p. 217.

DÍAZ, Lorenzo. Madrid, tabernas, botillerías y cafés. Op. Cit., p. 70 e 90

86

MACHADO, Leocadio. Op. Cit., p. 143.

A origem da palavra vem de gavatx, que em catalão significa estrangeiro. É uma maneira depreciativa, entre os espanhóis, de referir-se aos franceses e tudo que tenha a ver com França.

\section{8}

Hipocorístico de Manuel na Espanha. Segundo o Diccionario da Real Academia Española: "Persona de las clases populares de Madrid, que se distinguía por su traje y desenfado." Disponivel em <http://buscon.rae.es/drae/srv/ search?id=oJVpFq9maDXX2naVXe8y $>$ Acesso em: 15 jan. 2013

DIAZ, Lorenzo. Madrid, tabernas, botillerías y cafés. Op. Cit. p. 108

90

Ibidem, p. 75-76.

CABEZAS, Juan Antonio. Madrid, escenarios y personajes (selección de crónicas Madrid al día). Madrid: Editorial Prensa Española. 1968.
Entretanto, el pueblo seguía comiendo legumbres - el cocido madrileño formaba parte de los platos cotidianos ya en el siglo XV -, pasteles de carne hecho con hojaldre, empanadas y carnes cocinadas de muy diversas formas (en adobo, cocida, asada o guisada). ${ }^{84}$

Lógico que os abastados também comiam o cocido, com variações de ingredientes mais caros. Ademais, o vinho era uma bebida comum, com farto fornecimento e consumida por todos os setores da população, tendo sido sempre o líquido de predileção dos setores populares. ${ }^{85}$ Nesse período (XIX) algumas tabernas sinalizavam as procedências dos vinhos que comercializavam: de Arganda, Mósteles, San Martín, Hortaleza, Navalcarnero, Chinchón ou apenas um Vinho da Terra. ${ }^{86}$

Mas o que cabe observar aqui é que engalfinham-se duas etnias nas mesas e ruas de Madri do XIX. De um lado os gabachos, maneira depreciativa, entre os espanhóis, de referir-se aos franceses ${ }^{87}$. São os imitadores de moda forasteira, connoisseurs de perfumes e penteados. Na outra cabeceira estão os manolos $^{88}$. 0 termo é utilizado para designar os tipos populares, formados por sapateiros, ferreiros, taberneiros, açougueiros, trapeiros. ${ }^{89}$

São os devoradores de carne e vinho tabernais locais, como coloca Lorenzo Díaz:

El petimetre, ese afrancesado que enloquece por la vestimenta gabacha, está a la última de lo que sale del país. Sabe todo sobre peinados, cintas, telas, perfumes, encajes, colores... Todo vale para conseguir un éxito social que se considera accesible sólo mediante la imitación de lo francés. En comidas de chifla lo gabacho, lo que ha traído la Corte borbónica.

El manolo es carne de tasca, de mesón, de caracoles y callos. El manolo es el verdadero hijo de Madrid, arrogante y leal, temerario y indolente, sarcástico y medio revolucionario, que desdeña la fortuna y se ríe de la desgracia, mezcla de fanatismo oriental, de vanidad, pereza y valor españoles. Los manolos, a los que primero se ve Ilamó majos, formaban un pueblo aparte, extraño, violento, libertino, intolerante, enemigo jurado de los extranjeros, pero celoso de su independencia, revoltoso incorregible, patriota entusiasta, cien veces más vivo e interesante que el noble o golilla, entontecido por el ambiente de la Corte. ${ }^{90}$

Os cronistas da cidade do período contrariam em absoluto as versões de penúria relatadas por Dumas, Merimée, Gautier e Davillier. Há interpretações de que comia-se muito bem nas tabernas e casas de comida de Madrid do XIX. Juan Antonio Cabezas ${ }^{91}$ e Ricardo Sepúlveda referem-se aos cocidos (ou puchero) bem servidos nesses estabelecimentos, bem como pratos regionais (galegos, asturianos, bascos, andaluzes, catalães, etc.).

Deve-se levar em conta, evidentemente, que esses viajantes endinheirados pouco se aproximariam desses espaços (apenas Gautier se atreveu a provar algo e mesmo assim resignou-se nos líquidos) que sempre foram os mais aceitos entre os populares, por conta do hábito de tomar vinho e beber caldos (sopas) ou tomar um trago de aguardente pela manhã, entre outras bebidas. Até períodos recentes 0 álcool também era considerado alimento e muitas vezes representava a garantia de calorias baratas e combustivel para a lida. Montoliú Camps em seu estudo relata outros ingredientes consumidos nesses ambientes:

Las tabernas, por su parte, además de los citados caldos, servían vinos toledanos y 
92

MONTOLIÚ CAMPS, Pedro. Op. Cit., p. 214-215.

93

Ibidem, p. 218

94

DİAZ CAÑABATE, Antonio. Historia de una taberna. Madrid: Espasa Calpe, 1963. p. 19, 45, 177

95

MACHADO, Leocadio. Op. Cit., p. 119.

96

GÓMEZ FERNANDEZ, Francisco José. Las tabernas del viejo Madrid. Madrid Historico. Madrid. n.13, p. 48-53. p. 53. jan.-fev. 2008.

97

Segundo o Diccionario da Real Academia Española: "Vasija grande de barro cocido, y a veces vidriado, mucho más ancha por el medio que por el fondo y por la boca, y que encajada en un pie o aro, o empotrada en el suelo, sirve ordinariamente para guardar agua, aceite u otros líquidos." Disponivel em <http://buscon.rae.es/ drae/srv/search?id=BdeKdqfS9DXX2o0xWe4F> Acesso em 15 jan. 2013 andaluces a los que, a partir del siglo XVII, sumaron otras bebidas como el hipocrás (hecho con vino, azúcar, canela, almizcle y ámbar gris), la aloja (agua, levadura, miel, polvos de jengibre, canela, pimienta, clavo y nuez), la carraspada (vino tinto cocido con miel y especias), la calabriada (mezcla de vino blanco y tinto), la garnacha (realizada con tres zumos de uva, azúcar, canela y pimienta) y el agraz (hecho con uva verde no madura y guardaba en botellas de cuello alargado).

También se hizo muy habitual consumir las mañanas de mucho frío un vaso de aguardiente que solía acompañarse de un plato de letuario (confitura de naranja), de una galleta o de un buñuelo bañado en miel. Posteriormente surgirian los rosolís, que se hacian en Valdemoro, y que estaban compuestos de aguardientes mezclados con azúcar, canela y anis. ${ }^{92}$

No XVIII, além do cocido, surgem na cozinha popular madrilena: callos a la madrileña, gallina en pepitoria, sopas de ajo, purê de garbanzos, espárragos madrileños, huevos cocidos, bacalao a la cazuela, churros, buñuelos, barquillos rellenos de nata, dentre um rico leque de pratos que superavam 35 especialidades. ${ }^{93}$

Antonio Díaz Cañabate também esmiúça iguarias servidas na antiga taberna de Antônio Sanchez: torrijas (simplesmente um pedaço de pão frito com leite e açúcar, vendido por quinze cêntimos, um preço baixissimo), muito vinho, tomado por motivos múltiplos, inclusive para impedir a constipação, coelho com tomate (outro prato extremamente tradicional da comida popular madrilena). ${ }^{94}$

Esse cardápio relatado ainda é a base do que se come nas tabernas mais castiças da cidade. E ainda é possivel tomar um vinho de Chinchón ou San Martín. E pelo que se percebe da comida tabernal atual, pelo menos no que diz respeito aos estabelecimentos mais tradicionais, é certo que permanece a resistência contra esse medo atávico dos viajantes quanto ao cheiro e do gosto do alho e do azeite. A cozinheira da taberna continua preparando a sopa como quer. Sancho Panza respondia a Cervantes que não obedece nenhum rei porque só ele (Panza) é seu senhor e dono. E os madrilenos continuam, conforme ensinaram suas avós, esfregando alho cru no pão para preparar seus bocadillos.

0 tremor do cronista Enrique Sepúlveda de que a taberna capitulasse não se cumpriu. Vários são os casos de tabernas que suportaram até os dias atuais sob a gerência de madrilenos e de descendentes de errantes procedentes de locais diversos que entremearam a cultura manchega com outros pratos, bebidas e temperos.

De todo modo, há uma clara atitude de reiterar a taberna como lugar frequentado por tipos populares, borrachos e manolos. Foi das adegas do bairro de El Rastro, repletas de fumo, cante, vinho, jogos e rumores que Pepe Botella mandou recolher vinho à revelia para sua expedição real, enquanto a ralé se safava cantando: "Ya se fue por las ventas el rey Pepino, com un par de botellas para el camino." ${ }^{15}$ Foi das mesmas tascas que o povo saiu no dia 2 de maio de 1808 para enfrentar os franceses. ${ }^{96}$

Embora Dumas, Gautier, Davillier e Merimée tenham torcido seus narizes e paladares, como não poderia deixar de ser, o confronto entre os franceses e espanhóis foi resolvido no interior da taberna. Há relatos de um vinho especial que era vendido na Taberna de Antonio Sánchez. 0 tal Néctar de Baco era denominado o de "la cuba del francês" e era extraído de uma grande tinaja $^{97}$ que levava o número seis. Conta a lenda que durante a Guerra da 
GARCIA DE OTEYZA, Carlos Osório. Tabernas y tapas en Madrid. Madrid: Ediciones La Libreria, 2010. p. 41.
Independência os vizinhos trucidaram um soldado de Napoleão. Para rechaçar desforras, esconderam-no dentro de uma das cubas de vinho. Dizem que o contido líquido poderoso gozava de um parfum extraordinário e peculiar. ${ }^{98}$

\section{Referências Bibliográficas}

\section{Fontes Documentais}

BLACKBURN, Henry. Travelling in Spain in the Present Day. Londres: Sampson Low, Son \& Marston, 1866.

BYRNE, Julia Clara Pitt. Cosas de España. London, New York: Alexander Strahan, 1866.

CABEZAS, Juan Antonio. Madrid, escenarios y personajes (selección de crónicas Madrid al día). Madrid: Editorial Prensa Española. 1968.

DAVILLIER, Barón Ch.; DORÉ, Gustavo. Viaje por España. Madrid: Adalia, 1984.

DE AMICIS, Edmundo. España. Viaje durante el Reinado de Don Amadeo I. Madrid: Librería de Vicente Lopes, 1883.

DUMAS, Alexandre. De Paris a Cádiz: impressiones de viaje. Valencia: Pretextos, 2002

GAUTIER, Teófilo. Viaje por España. Barcelona: Mateu, 1971.

MERIMÉE, Prosper. Viajes a España. Madrid: Aguilar, 1988.

SEPÚLVEDA, Enrique. La vida en Madrid en 1886. Madrid: Librería de Fernando Fé, 1887.

La vida en Madrid en 1888. Madri: Librería de Ricardo Fé, 1889.

SEPÚLVEDA, Ricardo. Madrid Viejo: cronicas, avisos, costumbres, leyendas y descripciones. Madrid: Librería de Fernando, 1888.

\section{Bibliografia}

BARBUY, Heloisa. A cidade-exposição: comércio e cosmopolitismo em São Paulo (1860-1914). São Paulo: EDUSP, 2006.

BAUDELAIRE, Charles. As Flores do Mal. Rio de Janeiro: Nova Fronteira, 1985.

BENJAMIN, Walter. Passagens. Belo Horizonte/São Paulo: UFMG/Imprensa Oficial, 2006.

BESAS, Peter. Historia y anécdotas de las fondas madrileñas. Madrid: Ediciones La Librería, 2009.

CHARTIER, Roger. História Cultural: entre práticas e representações. Lisboa/ Rio de Janeiro: Difel/Bertrand do Brasil, 1995.

DÍAZ CAÑABATE, Antonio. Historia de una taberna. Madrid: Espasa Calpe, 1963.

DÍAZ, Lorenzo. Diez siglos de cocina en Madrid: de los mesones de ayer a los restaurantes de hoy. Barcelona: Folio, 1994. 

Espasa Calpe. 1991.

Madrid: bodegones, mesones, fondas y restaurantes. Cocina y sociedad (1412-1990). Madrid: Espasa Calpe. 1990.

DÍEZ BORQUE, José Maria. La vida española en el siglo de Oro según los extranjeros. Barcelona: Ediciones del Serbal, 1990.

GARCIA DE OTEYZA, Carlos Osório. Tabernas y tapas en Madrid. Madrid: Ediciones La Librería, 2010.

GÓMEZ FERNANDEZ, Francisco José. Las tabernas del viejo Madrid. In: Madrid Historico. Madrid. n.13, p. 48-53. jan.-fev. 2008.

JUNQUEIRA, Mary Anne. Elementos para uma discussão metodológica dos relatos de viagem como fonte para o historiador. In: ; FRANCO, Stella Maris Scatena. (orgs.) Cadernos de Seminários de Pesquisa. São Paulo: USP/Humanitas. 2011. v. 2. p. 44-61.

LÓPEZ CARCELÉN, Pedro. Atlas Ilustrado de la historia de Madrid. Madrid: Ediciones La Librería. 2013.

MACHADO, Leocadio. Historia del vino de Madrid. Madrid: Ediciones La Librería, 2002.

MONTOLIÚ CAMPS, Pedro. Enciclopedia de Madrid. Barcelona: Planeta, 2002.

PESSOA, Fernando. Ficções do Interlúdio 4: Poesias de Álvaro de Campos. Rio de Janeiro: Nova Fronteira, 1983.

REVILLA, Fidel; RAMOS, Rosalía. Historia Breve de Madrid. Madri: Ediciones La Librería, 2012.

SAID, Edward. Orientalismo: o Oriente como invenção do Ocidente. São Paulo: Companhia das Letras, 2007.

SAMORAL, Manuel. El siglo XIX: la utopía de libertad, orden y progreso. In:__ (org). Historia de Iberoamerica. Madri: Cátedra, 2008, p. 47-55.

SANTOS, Carlos Roberto Antunes. A alimentação e seu lugar na história: os tempos da memória gustativa. História: Questões \&t Debates, Curitiba, n. 42, p. 11-31. 2005.

SPINOLA, Carlos. Los cuatro jinetes del Apocalipsis de la gastronomía andaluza. In: Revista GastroSur, Cádiz, n. 3, p. 3-5, 2005. 